\title{
Socio-economic differences in food group and nutrient intakes among young women in Ireland
}

\author{
Daniel M. A. McCartney*, Katherine M. Younger, Joanne Walsh, Marie O’Neill, Claire Sheridan \\ and John M. Kearney \\ School of Biological Sciences, Dublin Institute of Technology, Kevin Street, Dublin 8, Republic of Ireland
}

(Submitted 14 September 2012 - Final revision received 27 March 2013 - Accepted 8 April 2013 - First published online 31 May 2013)

\begin{abstract}
The present study aimed to investigate socio-economic disparities in food and nutrient intakes among young Irish women. A total of 221 disadvantaged and seventy-four non-disadvantaged women aged 18-35 years were recruited. Diet was assessed using a diet history protocol. Of the total population, 153 disadvantaged and sixty-three non-disadvantaged women were classified as plausible dietary reporters. Food group intakes, nutrient intakes and dietary vitamin and mineral concentrations per MJ of energy consumed were compared between the disadvantaged and non-disadvantaged populations, as was compliance with dietary fibre, macronutrient and micronutrient intake guidelines. The disadvantaged women had lower intakes than the non-disadvantaged women of fruit, vegetables, fish, breakfast cereals, low-fat milk and wholemeal bread (all $P<0 \cdot 001)$, yogurt $(P=0 \cdot 001)$, low-fat spread $(P=0 \cdot 002)$ and fresh meat $(P=0 \cdot 003)$. They also had higher intakes of butter, processed red meats, white bread, sugar-sweetened beverages, fried potatoes and potato-based snacks (all $P<0 \cdot 001)$ and full-fat milk $(P=0 \cdot 014)$. Nutritionally, the disadvantaged women had higher fat, saturated fat and refined sugar intakes; lower dietary fibre, vitamin and mineral intakes; and lower dietary vitamin and mineral densities per MJ than their more advantaged peers. Non-achievement of carbohydrate $(P=0.017)$, fat $(P<0.001)$, saturated fat $(P<0 \cdot 001)$, refined sugar $(P<0 \cdot 001)$, folate $(P=0 \cdot 050)$, vitamin $\mathrm{C}(P<0.001)$, vitamin $\mathrm{D}(P=0.047)$ and $\mathrm{Ca}(P=0.019)$ recommendations was more prevalent among the disadvantaged women. Both groups showed poor compliance with Fe and Na guidelines. We conclude that the nutritional deficits present among these socially disadvantaged women are significant, but may be potentially ameliorated by targeted food-based interventions.
\end{abstract}

Key words: Nutrients: Dietary intakes: Low socio-economic status: Irish women

There is a substantial body of research demonstrating both increased morbidity ${ }^{(1,2)}$ and premature mortality ${ }^{(3)}$ among Irish adults of low socio-economic status (SES), in comparison with their more advantaged peers. International research has suggested that such health inequalities may be at least partially attributable to differences in food and nutrient intakes across the socio-economic spectrum ${ }^{(4)}$. However, while literature describing dietary and nutritional inequalities among Irish adults has been published ${ }^{(5-7)}$, it has been a challenge for the larger national nutrition surveys conducted in recent years $^{(8-11)}$ to capture the food and nutrient intake patterns of the very poorest members of Irish society. The methodological constraints that limit the recruitment of such subjects in national nutrition surveys have highlighted the need for focused, dedicated research in this area. For example, the Low Income Diet and Nutrition Survey (LIDNS) in the $\mathrm{UK}^{(12)}$ was commissioned specifically to examine food and nutrient intake patterns among a carefully selected population of low-SES consumers in that country.
Research in many countries has highlighted profound differences in food group and nutrient intakes across the socio-economic spectrum. For example, lower consumption of fruit and vegetables has been consistently demonstrated among low-SES groups in the $\mathrm{UK}^{(13)}$, Europe ${ }^{(14)}$, Norway ${ }^{(15)}$, the Netherlands ${ }^{(16)}$, Denmark ${ }^{(17)}$, Australia ${ }^{(18)}$, New Zealand ${ }^{(19)}$ and the USA ${ }^{(20)}$. Similarly, lower consumption of ready-to-eat breakfast cereals has been reported among low-SES groups in the $\mathrm{UK}^{(21)}$, France ${ }^{(22)}$, Spain ${ }^{(23)}$, the $\mathrm{USA}^{(24)}$ and Australia ${ }^{(25)}$, while lower wholemeal bread intakes have been observed among low-SES men and women in the $\mathrm{UK}^{(26)}$. Lower fish intakes have also been observed among low-SES respondents in Switzerland ${ }^{(27)}$, Italy ${ }^{(28)}$ and Spain ${ }^{(23)}$, while higher intakes of processed red meats ${ }^{(29-31)}$, chips and fried potatoes ${ }^{(32,33)}$, potato-based snacks ${ }^{(32,34)}$, white bread ${ }^{(32,35)}$, and sugarsweetened foods and drinks ${ }^{(26,36)}$ have also been widely reported among these socially disadvantaged groups.

These dietary differences have been shown to lead to unfavourable macronutrient ${ }^{(4,35)}$ and micronutrient ${ }^{(18)}$ intakes

Abbreviations: EAR, estimated average requirement; ED, electoral district; EI, energy intake; NMES, non-milk extrinsic sugar; SES, socio-economic status. 
among low-SES groups. The present study aimed to determine whether similar socio-economic differences in diet occur among young Irish women and, if so, whether they are associated with poorer nutritional intakes among these low-SES women.

\section{Methods \\ Data collection}

A total of 295 women aged 18-35 years were recruited from areas around Dublin using a de novo socio-economic sampling frame that ranked electoral districts (ED) based on a composite score for six socio-economic indicators. In order to construct this sampling frame, small-area population statistics were derived from national census data, enabling prevalence estimates for unemployment, low occupational social class, low socio-economic group, low formal education, single-parent household structure and local authority accommodation to be calculated for each of the 353 ED in Greater Dublin. Each of the ED was then ranked from 1 to 353 for each of these socio-economic parameters. For each ED, the ranking scores for each of these six socio-economic parameters were multiplied together. The product of the ranking scores for each ED was finally used to score each ED from 1 to 353 , with larger numbers indicating a greater level of overall disadvantage. Using this system, the most disadvantaged quintile of ED (i.e. the seventy-one ED with the largest scores) was identified. From these seventy-one ED, areas were identified in North, South, West and City Centre Dublin. Within these areas (four in North Dublin, three in South Dublin, four in West Dublin and four in the City Centre), fifteen recruitment sites (e.g. local community development schemes, training centres, crèches) were selected. Ultimately, 221 disadvantaged women were recruited from these sites. A reference population of seventy-four women was recruited from areas in the top four quintiles to establish a non-disadvantaged comparison group that would be broadly representative of the wider 'non-poor' female population in this age group.

Several indices were subsequently used to assess the SES of each respondent. These included educational attainment and occupational social class, in addition to material indices of disadvantage including 'at risk of poverty' status, relative deprivation and consistent poverty. At risk of poverty (relative income poverty) was calculated by comparing equivalised household income against the $60 \%$ median income threshold ${ }^{(37)}$. Relative deprivation was assessed by determining whether the respondents had experienced the enforced absence (due to financial constraint) of one or more basic necessities from a list of eight ${ }^{(37)}$, while consistent poverty was identified if a respondent reported being 'at risk of poverty' in addition to experiencing enforced absence of one or more of the eight basic markers of deprivation ${ }^{(37)}$. The derivation of relative deprivation is now defined as the enforced absence of two or more basic necessities from a revised list of eleven ${ }^{(38)}$; however, this itinerary had not been finalised or implemented during the design or early data collection phases of the present study.
Habitual dietary intake was assessed by an interviewerassisted questionnaire in a group setting, using a semistructured weekly diet history according to a previously described protocol ${ }^{(39)}$. A facilitator outlined each mealtime and inter-meal period to the group in turn, with each respondent recording each component of her typical weekly menu at the appropriate location on her diet history questionnaire. Thereafter, three fieldworkers (one dietitian and two finalyear nutrition and dietetics students) conducted face-to-face interviews with each respondent in the group to elicit the types of foods consumed at these meal- and snack times and the frequency with which these foods were consumed. Portion sizes for each food were quantified using verbal descriptions from the respondents expressed in terms of typical household measures and were further explicated using an atlas of food portion sizes ${ }^{(40)}$ and an itinerary of average portion sizes and typical weights of common foods as required $^{(41)}$. Information regarding the type, brand, frequency and dosage of any dietary supplements taken was also sought. A new food code was created for each of these supplements in a nutrient analysis package (Weighed Intake analysis Software Package (WISP) version 3.0; (C) Tinuviel Software Limited, 2005) using nutritional composition data derived from the manufacturer or taken directly from the nutrition label on the product. Where the brand was unknown to the respondent, the food code for the most commonly cited brand of that supplement type after all dietary records had been entered was used as the default.

Quantitative demographic, ecological, socio-economic, health behavioural and attitudinal data were simultaneously collected by a questionnaire at this time. Body weight was also measured to the nearest $0 \cdot 2 \mathrm{~kg}$ using a Seca Compact Digital Floor Scale III, model 888 (Seca Limited), while height was measured to the nearest $0.5 \mathrm{~cm}$ using a collapsible 'Leicester Height Measure' stadiometer (CMS Weighing Equipment). Waist circumference was measured on the left hand side around the umbilicus, at the mid-point between the lower rib margin and the supra-iliac crest on the mid-axillary line. These measurements were taken to the nearest $0.5 \mathrm{~cm}$ with a Seca Circumference Measuring Tape model 200 (Seca Limited), held snugly against the skin as described in the North/South Ireland Food Consumption Survey (NSIFCS) ${ }^{(42)}$. Overall, anthropometric indices (weight, height and waist circumference) were measured for 292 of the 295 respondents.

\section{Data management}

For each respondent, the total weekly intake for each food in the diet history (i.e. the $g$ per portion multiplied by the number of servings per week) and each dietary supplement was entered into a MS Excel ${ }^{\circledR}$ spreadsheet. Using the formula function, the weekly intake data were then divided by 7 to yield an average daily intake (i.e. amount per d) for all of the foods and supplements recorded in the respondent's diet history. These average daily intakes for each food and supplement were subsequently entered into WISP version 3.0, which generated food group and nutrient intake estimates 
based on McCance and Widdowson's The Composition of Foods 6th Edition ${ }^{(43)}$ and Supplements.

WISP version 3.0 generated seventeen default food groups, from which ten broad food groups were initially created. In order to assess differences in the intakes of foods within these groups, six of the ten food groups (milk and dairy foods, starchy carbohydrates, meat and meat products, beverages, potatoes and fish) were disaggregated manually. This was done by examining all of the 295 diet records from WISP, highlighting the foods in each of these six broad food groups, and then separating the foods in each group into their constituent subgroups. This created twenty-three new subgroups from the six original larger food groups, including categories such as low-fat milk and full-fat milk; white, brown and wholemeal breads; and sugar-sweetened and non-sugar-sweetened beverages, the latter of which included all teas, coffees, squashes and waters. These disaggregated food group data were added to the original food and nutrient intake data from WISP, and these were then merged with the demographic, ecological, socio-economic, health behavioural and attitudinal data, creating a final relational database that covered all of these parameters for all the 295 respondents. The full database was exported to a statistical software package (SPSS version 16.0; SPSS, Inc., 2007) for subsequent analyses.

To address the issue of dietary misreporting, the 292 respondents for whom body weight data were available were stratified into one of four relative physical activity categories, based on habitual vigorous activity levels and estimated daily sitting times. In order to do this, the respondents were asked questions adapted from the short version of the International Physical Activity Questionnaire (IPAQ) ${ }^{(44)}$ about how long they were seated for on a typical weekday and a typical weekend day, and about their duration of vigorous physical activity on a typical weekday and a typical weekend day. Weighted average daily durations spent at each of these activity levels were calculated from these data, permitting the respondents to be classified into one of three tertiles for sitting time (low, moderate or high) and as 'exercisers' or 'non-exercisers' based on their participation or nonparticipation in vigorous activity. Those in the highest tertile for sitting time (i.e. the least active) were attributed a 'sedentarism' score of 1 , with those in the moderate category receiving a score of 2 and those in the lowest category (i.e. the most active) receiving a score of 3 . Non-exercisers who did not participate in vigorous activity were similarly given a score of 1 , while the 'exercisers' were allocated a score of 2 . The respondents then had their sedentarism (sitting) scores and their vigorous activity scores multiplied together, generating overall relative physical activity scores from 1 (least active) to 6 (most active). These overall scores were finally used to classify the 292 respondents into four relative activity categories: low ( $n$ 64); low to moderate ( $n$ 96); moderate to high ( $n$ 66) and high ( $n$ 66).

Based on published estimates of typical physical activity levels among women ${ }^{(45-47)}$ and considering the demonstrably low overall levels of vigorous activity in our study population (two-thirds of participants performed no vigorous activity at all), this cohort was deemed to have habitual levels that lay at the lower reaches of the documented physical activity spectrum for young women. Accordingly, the four relative physical activity categories were 'mapped' to a series of physical activity level estimates (1.40, 1.48, 1.56 and 1.64) according to previously described protocols ${ }^{(48)}$. Lower physical activity level 'cut-off' thresholds for the respondents in each physical activity level category were then calculated ${ }^{(48)}$. Those whose energy intake (EI) divided by their calculated BMR (EI/BMR) fell below the calculated cut-off threshold for their category were classified as dietary 'under-reporters' ( $n$ 53), while in all categories, those with an EI/BMR greater than 2.5 were classified as dietary 'over-reporters' ( $n$ 23). These under-reporters and over-reporters were excluded from further dietary and nutrient analyses.

\section{Statistical analysis}

Compliance with dietary fibre, macronutrient, vitamin and mineral intake guidelines was compared between the disadvantaged and non-disadvantaged groups, using crosstabulation with $\chi^{2}$ analyses and reporting Yates' continuity correction for all $2 \times 2$ analyses. For the macronutrients, this first necessitated that their percentage contribution to food EI (i.e. to EI after the contribution from alcohol had been excluded) be derived. Notwithstanding the fact that these are population guidelines, the respondents were categorised as 'compliers' if their intake exceeded the population guideline (in the case of carbohydrate and protein) or fell below the population guideline (in the case of total fat, saturated fat and non-milk extrinsic sugars (NMES)). 'Non-compliers' for the various macronutrients were those whose percentage of food energy fell below the population guideline in the case of carbohydrate and protein and those whose percentage of food energy fell above the population guideline in the case of total fat, saturated fat and NMES. In addition to macronutrient compliance, dichotomous categorical variables were also created to compare compliance with dietary fibre, NSP, alcohol, vitamin and mineral intake guidelines between the groups, again by means of cross-tabulation with $\chi^{2}$ analyses. Compliance thresholds for dietary fibre and NSP were defined according to the WHO/Food and Agriculture Organization $^{(49)}$ and UK Department of Health ${ }^{(50)}$ guidelines, respectively. Compliance thresholds for macronutrient intakes were defined according to the UK percentage food energy guidelines ${ }^{(50)}$ and Irish alcohol unit intake guidelines ${ }^{(51)}$. For each vitamin and mineral, the compliance threshold was defined as the Irish estimated average requirement $(\mathrm{EAR})^{(52)}$, with the exception of $\mathrm{Na}$, where in the absence of an EAR, the compliance threshold was defined at the population maximum recommended intake ${ }^{(53)}$.

All of the food group intakes were non-normally distributed, and intake comparisons between the disadvantaged and non-disadvantaged populations were made by non-parametric Mann-Whitney $U$ tests. The percentage of consumers for each food group was also compared between the disadvantaged and non-disadvantaged populations. This was done by first classifying each respondent as a consumer (intake $>0 \mathrm{~g} / \mathrm{d}$ ) or a non-consumer (intake $=0 \mathrm{~g} / \mathrm{d}$ ) for each of the different food groups of interest. These dichotomous categorical 
variables were then individually cross-tabulated against disadvantaged/non-disadvantaged status, with $\chi^{2}$ analyses and Yates' continuity correction being applied in each case to determine the statistical significance of their associations.

Differences in energy, dietary fibre and macronutrient intakes between the disadvantaged and non-disadvantaged populations were analysed using parametric independent samples $t$ tests for those whose intakes were normally distributed (energy, carbohydrate, total fat, saturated fat, monounsaturated fat, polyunsaturated fat and protein) and by non-parametric Mann-Whitney $U$ tests for those whose intakes were non-normally distributed (dietary fibre, NSP, NMES, cholesterol and alcohol). Macronutrient intakes were compared between the disadvantaged and non-disadvantaged populations with the contribution of alcohol excluded (i.e. comparison of percentages of energy from food only). This was done to ensure that high alcohol intakes did not artifactually reduce the calculated percentage of energy derived from fat, saturated fat or NMES, leading to erroneous conclusions about the overall quality of such diets.

Differences in vitamin and mineral intakes and dietary micronutrient density between the disadvantaged and nondisadvantaged groups were similarly assessed by parametric independent samples $t$ tests for normally distributed parameters ( $\mathrm{Na}, \mathrm{Zn}$ and $\mathrm{P}$ ) and by non-parametric MannWhitney $U$ tests for non-normally distributed parameters (vitamins $\mathrm{A}, \mathrm{B}_{1}, \mathrm{~B}_{2}, \mathrm{~B}_{5}, \mathrm{~B}_{6}, \mathrm{~B}_{12}, \mathrm{C}, \mathrm{D}$ and $\mathrm{E}$, niacin, folate, carotene, $\mathrm{K}, \mathrm{Fe}, \mathrm{Ca}, \mathrm{Mg}$ and $\mathrm{Cu}$ ).

Vitamin and mineral intake and compliance analyses were performed with dietary supplements included to compare total intakes and adequacy of these nutrients according to SES. Vitamin and mineral density analyses, however, were performed with supplements excluded to assess whether there were differences in the dietary concentration of these micronutrients between the two groups.
The two-sided significance of all results was assessed at the $P<0.05$ level.

The present study was conducted according to the guidelines laid down in the Declaration of Helsinki, and all procedures involving human subjects were approved by the Dublin Institute of Technology Ethics Committee, 2005. Written informed consent was obtained from all subjects.

\section{Results}

\section{Sample population}

The disadvantaged population differed significantly from the non-disadvantaged population in terms of both the social (occupational social class, education and single-adult family structure) and material (income, deprivation and consistent poverty) indices of disadvantage used by the Irish Central Statistics Office ${ }^{(37)}$ (Table 1). The disadvantaged women in the present study also had rates of relative income poverty or 'at risk of poverty' (51.1\%), relative deprivation (40.5\%) and consistent poverty (25\%) that were substantially greater than those observed in the national population (16.5, 24.4 and $5 \cdot 1 \%$, respectively). The disadvantaged respondents' poverty rates were also considerably higher than those of identifiably vulnerable population groups in Irish national surveys, such as those in lone-parent households $(37.6 \%$ relative income poverty rate) and the unemployed ( $17.5 \%$ consistent poverty rate) ${ }^{(54)}$. While all the respondents were aged $18-35$ years, the 'disadvantaged' sample was younger than the reference 'non-disadvantaged' peer group (25.1 (SD 5.7) v. 26.9 (SD 3.9) years, $P=0.011$ ). Overall, $90 \cdot 7 \%$ of the overall population was Caucasian Irish, with $3.6 \%$ from other EU member states, $3.4 \%$ of Black African ethnicity, $1.7 \%$ classified as travellers and $0.6 \%$ from Asia. This compared to the most recent National Census data at the time (2006), which classified $87.4 \%$ of the population as Irish, $0.5 \%$ as Irish Travellers, 6.9\% as "Any

Table 1. Socio-economic characteristics of the full study population ( $n$ 295)

\begin{tabular}{|c|c|c|c|}
\hline & Definition & $\begin{array}{l}\text { Percentage of disadvantaged } \\
\text { population }(n 221)\end{array}$ & $\begin{array}{c}\text { Percentage of advantaged } \\
\text { population }(n 74)\end{array}$ \\
\hline Disadvantage & Recruited from a site within the lowest quintile of ED & $100 \cdot 0$ & 0.0 \\
\hline Low social class & $\begin{array}{l}\text { Social class: (4) skilled manual, (5) semi-skilled or } \\
\text { (6) unskilled }\end{array}$ & $63 \cdot 3$ & 0.0 \\
\hline $\begin{array}{l}\text { Low socio-economic } \\
\text { group }\end{array}$ & $\begin{array}{l}\text { Socio-economic group: (E) manual skilled, } \\
(F) \text { semi-skilled or }(G) \text { unskilled }\end{array}$ & $43 \cdot 4$ & 0.0 \\
\hline Low education & None, primary or intermediate education & $54 \cdot 8$ & 0.0 \\
\hline Early school leaving & Left school aged 16 years or under & $46 \cdot 6$ & $2 \cdot 7$ \\
\hline $\begin{array}{l}\text { Relative income } \\
\text { poverty }^{*}\end{array}$ & $\begin{array}{l}\text { Equivalised income less than } 60 \% \text { of the median income } \\
\text { (i.e. }<€ 208 \cdot 71 / \text { week) }\end{array}$ & $51 \cdot 1$ & $2 \cdot 7$ \\
\hline Relative deprivation $\dagger$ & Lacking one or more of the eight basic deprivation indicators & 40.5 & $4 \cdot 1$ \\
\hline Consistent poverty & $\begin{array}{l}\text { Equivalised income }<€ 208 \cdot 71 / \text { week and lack } \geq 1 \text { of the } \\
\text { eight basic deprivation indicators }\end{array}$ & $25 \cdot 0$ & 1.4 \\
\hline Benefit entitlement & Entitled to social welfare payments & $63 \cdot 6$ & $10 \cdot 8$ \\
\hline Medical card status & Entitled to a medical card & $69 \cdot 2$ & 1.4 \\
\hline Single-adult family unit & Family unit comprising a single adult and one or more children & $44 \cdot 8$ & 0.0 \\
\hline
\end{tabular}

ED, electoral district.

${ }^{\star}$ Equivalised income calculated on 1.0 (first adult), 0.5 (second and subsequent adults) and 0.3 (children under 14 years) scales used by the Central Statistics Office, Ireland ${ }^{(37)}$

†The eight 'basic necessities' selected by the Central Statistics Office ${ }^{(37)}$ to describe relative deprivation in Ireland are not having new, but second-hand clothes, a meal with meat, chicken or fish every second day, a warm, water-proof coat, two pairs of strong shoes, and a roast or its equivalent once per week or having debt problems arising from normal living expenses (or availing of charity), a day in the last 2 weeks without a substantial meal and needing to go without eating during the last year through lack of money. 
other White background', $1 \cdot 0 \%$ as African, $0 \cdot 1 \%$ as 'Any other Black background', $0.4 \%$ as Chinese, $0.9 \%$ as 'Any other Asian background' and $1 \cdot 1 \%$ as 'Other including Mixed background,(55).

\section{Food group intakes}

Median intakes of fruit and fruit juices, vegetables, breakfast cereals, low-fat milk, yogurt, low-fat spread, poultry, wholemeal bread, non-sugar-sweetened beverages, fresh fish and tinned fish were all significantly lower among the disadvantaged women than among their more affluent peers. Conversely, median intakes of full-fat milk, butter, red meats, processed red meats, white bread, sugar-sweetened beverages, fried and roasted potatoes and potato-based snacks were all significantly higher among the disadvantaged women than among the non-disadvantaged women (Table 2).

For fruit, vegetables, breakfast cereals, low-fat milk, butter, processed red meats, wholemeal bread, sugar-sweetened beverages, fried and roasted potatoes, potato-based snack foods and fish, two- to threefold disparities in intake (and considerably more in some cases) were observed, indicating profound dietary differences between the two groups (Table 2).

Most of these discrepancies in food group intake were mediated by differences in both 'intake level' (i.e. portion size and frequency of consumption) and 'prevalence of consumption' (i.e. the percentage of consumers within the respective populations). For example, there were significantly fewer consumers of fruit juices (69v. 94\%), breakfast cereals (58 v. 86\%), low-fat milk (24 v. 64\%), oily fish ( 4 v. 36\%) and tinned fish (15v. 47\%) (all $P<0.001$ ), yogurt (36 v. 61\%, $P=0.001$ ), low-fat spread (20 v. 39\%, $P=0.007$ ), poultry ( 87 v. 98\%, $P=0.018$ ), wholemeal bread (49v. 73\%, $P=0.002$ ), non-sugar-sweetened beverages (82 v. $95 \%$, $P=0.020)$ and fresh fish (12 v. 31\%,P=0.001) in the disadvantaged group than in the non-disadvantaged group. A higher percentage of disadvantaged than non-disadvantaged women consumed full-fat milk (80 v. 58\%, $P=0.001$ ), butter (80 v. 59\%, $P=0.002$ ), white bread (88 v. 64\%, $P<0.001$ ), sugar-sweetened beverages ( $82 v .61 \%, P=0.002)$, fried and roasted potatoes (88v. 73\%, $P=0.020)$ and potato-based snacks (71 v. 38\%, $P<0 \cdot 001)$.

However, when non-consumers were removed, considerable differences in intake level between the disadvantaged and non-disadvantaged consumers persisted for several food groups. Disadvantaged consumers had higher daily intakes of butter (14 v. $7 \mathrm{~g}, P=0.002$ ), red meats (47v. 39g, $P=0.002$ ), processed red meats (40 v. $20 \mathrm{~g}, P<0.001$ ), white bread (78 v. 31 g, $P<0.001)$, sugar-sweetened beverages (601 v. $200 \mathrm{~g}, P<0 \cdot 001$ ), fried and roasted potatoes (89 $v$. $30 \mathrm{~g}, \quad P<0.001)$ and potato-based snacks (17 v. 9g, $P<0.001)$; and lower daily intakes of fruit and fruit juices (145 v. 214g, $P=0.006$ ), breakfast cereals (17 v. $30 \mathrm{~g}$,

Table 2. Differences in food group consumption between the disadvantaged and non-disadvantaged respondents* $(n 216)$

\begin{tabular}{|c|c|c|c|c|c|c|}
\hline \multirow[b]{2}{*}{ Food groups } & \multirow[b]{2}{*}{ Disaggregated food groups } & \multicolumn{2}{|c|}{ Disadvantaged ( $n$ 153) } & \multicolumn{2}{|c|}{ Non-disadvantaged ( $n$ 63) } & \multirow[b]{2}{*}{$P$} \\
\hline & & Amount $(\mathrm{g} / \mathrm{d}) \dagger$ & IQR (g) & Amount $(\mathrm{g} / \mathrm{d}) \dagger$ & IQR (g) & \\
\hline \multirow[t]{2}{*}{ Fruit and vegetables } & Fruit and fruit juices & 74 & 196 & 200 & 219 & $<0.001$ \\
\hline & Vegetables & 72 & 75 & 194 & 116 & $<0.001$ \\
\hline Breakfast cereals & All types of cereals & 4 & 18 & 29 & 44 & $<0.001$ \\
\hline \multirow[t]{7}{*}{ Dairy products } & Full-fat milk & 96 & 140 & 49 & 150 & 0.014 \\
\hline & Low-fat milk & 0 & 0 & 63 & 154 & $<0.001$ \\
\hline & Cheese & 6 & 20 & 13 & 21 & 0.057 \\
\hline & Yogurt & 0 & 36 & 20 & 90 & 0.001 \\
\hline & Butter & 11 & 18 & 4 & 8 & $<0.001$ \\
\hline & Non-butter spread & 0 & 0 & 0 & 0 & 0.330 \\
\hline & Low-fat spread & 0 & 0 & 0 & 8 & 0.002 \\
\hline \multirow{4}{*}{ Meat and meat products } & Red meats & 46 & 41 & 33 & 35 & 0.003 \\
\hline & Poultry & 40 & 48 & 63 & 52 & $<0.001$ \\
\hline & Processed red meats & 37 & 45 & 17 & 22 & $<0.001$ \\
\hline & Processed poultry & 0 & 0 & 0 & 0 & 0.164 \\
\hline \multirow[t]{2}{*}{ Starchy carbohydrates } & White bread & 71 & 60 & 12 & 48 & $<0.001$ \\
\hline & Wholemeal bread & 0 & 41 & $42 \cdot 5$ & 93 & $<0.001$ \\
\hline \multirow[t]{3}{*}{ Sweet foods and drinks } & Sweet foods and confectionery & 67 & 92 & 64 & 52 & 0.498 \\
\hline & Sugar-sweetened beverages & 428 & 790 & 71 & 264 & $<0.001$ \\
\hline & Non-sugar-sweetened beverages & 520 & 880 & 1061 & 877 & $<0.001$ \\
\hline \multirow[t]{3}{*}{ Potatoes } & Plain & 56 & 60 & 50 & 50 & 0.135 \\
\hline & Fried/roasted & 74 & 88 & 24 & 47 & $<0.001$ \\
\hline & Potato-based snacks & 11 & 28 & 0 & 6 & $<0.001$ \\
\hline \multirow[t]{5}{*}{ Fish and fish products } & Overall fish & 0 & 21 & 26 & 36 & $<0.001$ \\
\hline & Fresh & 0 & 0 & 0 & 14 & 0.001 \\
\hline & Oily & 0 & 0 & 0 & 17 & 0.960 \\
\hline & Crumbed/battered & 0 & 0 & 0 & 0 & $<0.001$ \\
\hline & Tinned & 0 & 0 & 0 & 24 & $<0.001$ \\
\hline
\end{tabular}

IQR, interquartile range.

${ }^{*}$ All food group intakes were non-normally distributed, with intake comparisons between the disadvantaged and non-disadvantaged populations being performed using non-parametric Mann-Whitney $U$ tests.

$\uparrow$ Median values used for comparison. 
$P<0.001$ ), poultry (43v.66g, $P=0.004$ ), wholemeal bread (41 v. $71 \mathrm{~g}, P=0.012$ ) and non-sugar-sweetened beverages (671 v. $1074 \mathrm{~g}, P=0.001$ ) than the non-disadvantaged women who consumed these food groups.

\section{Nutrient compliance}

Energy, fibre and macronutrients. Non-compliance with macronutrient intake guidelines occurred more often among the disadvantaged women, who were significantly more likely than their non-disadvantaged peers to fall short of the recommended carbohydrate intake and to exceed the recommended intake guidelines for fat, saturated fat and NMES. Additionally, three times more disadvantaged than non-disadvantaged respondents exceeded the recommended $300 \mathrm{mg}$ of dietary cholesterol per d, while a considerable majority of both groups failed to meet dietary fibre and $n$ - 3 fatty acid guidelines (Table 3).

Micronutrients. While differences in vitamin and mineral compliance were less pronounced between the two groups, the disadvantaged women were significantly more likely to fall short of the EAR for folate, vitamin C, vitamin D and $\mathrm{Ca}$ (Table 3). In the case of folate, while $35.3 \%$ of the disadvantaged women (and 20.6\% of the non-disadvantaged women) failed to achieve the EAR of $230 \mu \mathrm{g} / \mathrm{d}^{(52)}$, just $0.5 \%$ of the disadvantaged women and only $5.4 \%$ of the non-disadvantaged women took a $400 \mu \mathrm{g} / \mathrm{d}$ supplement of disadvantaged and non-disadvantaged respondents ( $n$ 216) folic acid as recommended for all women of child-bearing potential $^{(52)}$. A significant percentage of both populations also failed to achieve the requisite intake of vitamin $\mathrm{C}$, vitamin A, Fe, Ca and especially vitamin D, while a majority of both groups exceeded the recommended intake of $\mathrm{Na}$.

\section{Nutrient intakes}

Energy, dietary fibre and macronutrients. Mean and median energy consumption and dietary fibre and macronutrient intakes differed considerably between the two groups, when the contribution from alcohol was excluded (Table 4). Mean daily EI was $1.25 \mathrm{MJ}$ greater in the disadvantaged group than in the non-disadvantaged group (1.46 MJ with alcohol included). Dietary fibre, NSP, carbohydrate and protein intakes were lower, and fat, saturated fat, NMES and cholesterol intakes were higher, among the disadvantaged respondents in comparison with their more affluent peers.

Micronutrients. Mean and median vitamin and mineral intakes differed substantially between the disadvantaged and non-disadvantaged women, with the contribution from supplements both included and excluded. With supplements included, median intakes of vitamin $B_{2}$, niacin, vitamin $B_{5}$, vitamin $\mathrm{B}_{6}$, folate, vitamin $\mathrm{C}$, carotene, vitamin $\mathrm{D}$ and vitamin $\mathrm{E}$ were all lower among the disadvantaged women in comparison with the non-disadvantaged women (Table 5). Regarding mineral consumption, median intakes of $\mathrm{Mg}$ were

Table 3. Differences in achievement of the recommended dietary fibre, macronutrient, cholesterol, alcohol, vitamin and mineral intakes between the

\begin{tabular}{|c|c|c|c|c|}
\hline \multirow[b]{2}{*}{ Nutrients including supplements } & \multirow[b]{2}{*}{ Population guideline $^{*}$} & \multicolumn{2}{|c|}{$\begin{array}{l}\text { Percentage of individuals falling } \\
\text { outside the recommended guidelines }\end{array}$} & \multirow[b]{2}{*}{$P$} \\
\hline & & Disadvantaged ( $n$ 153) & Advantaged (n 63) & \\
\hline Dietary fibre (Southgate) $(\mathrm{g} / \mathrm{d})$ & $>25 \mathrm{~g} / \mathrm{d}^{(49)}$ & $99 \cdot 3$ & $98 \cdot 4$ & 1.000 \\
\hline$\%$ Food energy from carbohydrate & $>50 \%$ food energy ${ }^{(50)}$ & $49 \cdot 0$ & $30 \cdot 2$ & 0.017 \\
\hline$\%$ Food energy from non-milk extrinsic sugars & $<11 \%$ food energy ${ }^{(50)}$ & $59 \cdot 5$ & $30 \cdot 2$ & $<0.001$ \\
\hline$\%$ Food energy from fat & $<35 \%$ food energy ${ }^{(50)}$ & 73.9 & $34 \cdot 9$ & $<0.001$ \\
\hline$\%$ Food energy from saturated fat & $<11 \%$ food energy ${ }^{(50)}$ & 88.9 & $65 \cdot 1$ & $<0.001$ \\
\hline Cholesterol $(\mathrm{mg} / \mathrm{d})$ & $<300 \mathrm{mg} / \mathrm{d}$ & $37 \cdot 9$ & $12 \cdot 7$ & $<0.001$ \\
\hline Alcohol (units/week) & $<14$ units $\left(140 \mathrm{ml}\right.$ ethanol)/week ${ }^{(51)}$ & $37 \cdot 7$ & $25 \cdot 4$ & 0.114 \\
\hline Vitamin $\mathrm{B}_{1}(\mathrm{mg} / \mathrm{d}) \dagger$ & $>0.6 \mathrm{mg} / \mathrm{d}^{(52)}$ & $1 \cdot 3$ & 0.0 & 0.896 \\
\hline Vitamin $B_{2}(\mathrm{mg} / \mathrm{d})$ & $>1.1 \mathrm{mg} / \mathrm{d}^{(52)}$ & $15 \cdot 7$ & $7 \cdot 9$ & 0.194 \\
\hline $\operatorname{Niacin}(\mathrm{mg} / \mathrm{d}) \ddagger$ & $>1.3 \mathrm{mg} / \mathrm{MJ}$ per $\mathrm{d}^{(52)}$ & $6 \cdot 5$ & $0 \cdot 0$ & 0.085 \\
\hline Vitamin $B_{6}(\mu \mathrm{g} / \mathrm{g}$ protein per $\mathrm{d}) \S$ & $>13 \mu \mathrm{g} / \mathrm{g}$ protein per $\mathrm{d}^{(52)}$ & 0.7 & $0 \cdot 0$ & 1.000 \\
\hline Vitamin $B_{12}(\mu \mathrm{g} / \mathrm{d})$ & $>1.0 \mu \mathrm{g} / \mathrm{d}^{(52)}$ & 0.0 & 0.0 & 1.000 \\
\hline Folate $(\mu \mathrm{g} / \mathrm{d})$ & $>230 \mu \mathrm{g} / \mathrm{d}^{(52)}$ & $35 \cdot 3$ & $20 \cdot 6$ & 0.050 \\
\hline Vitamin C (mg/d) & $>46 \mathrm{mg} / \mathrm{d}^{(52)}$ & $30 \cdot 7$ & $6 \cdot 3$ & $<0.001$ \\
\hline Vitamin $A(\mu g / d)$ & $>400 \mu \mathrm{g} / \mathrm{d}^{(52)}$ & $54 \cdot 2$ & $65 \cdot 1$ & 0.190 \\
\hline Vitamin D $(\mu \mathrm{g} / \mathrm{d}) \|$ & $>5 \mu \mathrm{g} / \mathrm{d}$ & $80 \cdot 4$ & $66 \cdot 7$ & 0.047 \\
\hline$n-3$ PUFA (mg/d) & $>0.2 \%$ dietary energy ${ }^{(50)}$ & $85 \cdot 0$ & $76 \cdot 2$ & 0.179 \\
\hline $\mathrm{Na}(\mathrm{mg} / \mathrm{d}) \mathrm{q}$ & $<2400 \mathrm{mg} / \mathrm{d}^{(53)}$ & $79 \cdot 1$ & $68 \cdot 3$ & $0 \cdot 129$ \\
\hline $\mathrm{Fe}(\mathrm{mg} / \mathrm{d})$ & $>10.8 \mathrm{mg} / \mathrm{d}^{(52)}$ & $49 \cdot 7$ & $38 \cdot 1$ & 0.161 \\
\hline $\mathrm{Ca}(\mathrm{mg} / \mathrm{d})$ & $>615 \mathrm{mg} / \mathrm{d}^{(52)}$ & $24 \cdot 8$ & 9.5 & 0.019 \\
\hline $\mathrm{Zn}(\mathrm{mg} / \mathrm{d})$ & $>5.5 \mathrm{mg} / \mathrm{d}^{(52)}$ & 8.5 & $3 \cdot 2$ & 0.270 \\
\hline $\mathrm{Cu}(\mathrm{mg} / \mathrm{d})$ & $>0.8 \mathrm{mg} / \mathrm{d}^{(52)}$ & $7 \cdot 8$ & $19 \cdot 0$ & 0.032 \\
\hline$P(\mathrm{mg} / \mathrm{d})$ & $>400 \mathrm{mg} / \mathrm{d}^{(52)}$ & 0.0 & 0.0 & 1.000 \\
\hline
\end{tabular}

${ }^{*}$ Population intake guidelines defined in terms of the WHO/Food and Agriculture Organization guidelines on dietary fibre ${ }^{(49)}$, UK Department of Health guidelines on macronutrient intake ${ }^{(50)}$, Irish alcohol intake guidelines ${ }^{(51)}$ and current Irish estimated average requirements (EAR) ${ }^{(52)}$.

†EAR for vitamin $B_{1}$ set at $72 \mu \mathrm{g} / \mathrm{MJ}$ per $\mathrm{d}$ and assumed at $0.6 \mathrm{mg} / \mathrm{d}$ for a daily energy intake of approximately $8.4 \mathrm{MJ}$.

†EAR for niacin set at $1.3 \mathrm{mg} / \mathrm{MJ}$ per $\mathrm{d}$ and assumed at $11 \mathrm{mg} / \mathrm{d}$ for a daily energy intake of approximately $8.4 \mathrm{MJ}$.

$\S$ EAR for vitamin $B_{6}$ set at $13 \mu \mathrm{g} / \mathrm{g}$ protein per $\mathrm{d}$ and assumed at $1.1 \mathrm{mg} / \mathrm{d}$ for a daily protein intake of approximately $85 \mathrm{~g}$.

$\|$ EAR for vitamin $D$ assumed at $5 \mu \mathrm{g} / \mathrm{d}$ (i.e. half of the maximum of the current RDA).

I Target maximum recommended intake set at $2400 \mathrm{mg} / \mathrm{d}$ by the Food Safety Authority of Ireland ${ }^{(53)}$. 
Table 4. Differences in energy, dietary fibre and macronutrient intakes (excluding alcohol) between the disadvantaged and non-disadvantaged respondents*

(Mean values and standard deviations; medians and interquartile ranges (IQR), $n$ 216)

\begin{tabular}{|c|c|c|c|c|c|c|c|c|c|c|}
\hline \multirow[b]{3}{*}{ Macronutrients } & \multirow[b]{3}{*}{ Recommended daily intake } & \multicolumn{8}{|c|}{ Food energy (excluding energy from alcohol) } & \multirow[b]{3}{*}{$P$} \\
\hline & & \multicolumn{4}{|c|}{ Disadvantaged ( $n$ 153) } & \multicolumn{4}{|c|}{ Non-disadvantaged ( $n$ 63) } & \\
\hline & & Mean & SD & Median & IQR & Mean & SD & Median & IQR & \\
\hline Energy (kcal) & Approximately $2000 \mathrm{kcal} / \mathrm{d}$ & 2208 & 560 & 2130 & 823 & 1906 & 374 & 1792 & 514 & $<0.001$ \\
\hline Energy (MJ) & Approximately $8.4 \mathrm{MJ} / \mathrm{d}$ & $9 \cdot 28$ & 2.35 & 8.97 & 3.43 & 8.03 & 1.57 & 7.56 & $2 \cdot 17$ & $<0.001$ \\
\hline $\begin{array}{l}\text { Dietary fibre } \\
\quad \text { (Southgate) (g/d) }\end{array}$ & $>25 \mathrm{~g} / \mathrm{d}^{49)}$ & $10 \cdot 1$ & 3.9 & $9 \cdot 8$ & 4.9 & $12 \cdot 6$ & 4.5 & 12.5 & $5 \cdot 8$ & $<0.001$ \\
\hline NSP (Englyst) (g/d) & $>18 \mathrm{~g} / \mathrm{d}^{50)}$ & $11 \cdot 7$ & $3 \cdot 8$ & $11 \cdot 4$ & 4.7 & $15 \cdot 0$ & $5 \cdot 0$ & 14.5 & 7.2 & $<0.001$ \\
\hline $\begin{array}{l}\text { Carbohydrate } \\
\text { (\% energy) }\end{array}$ & $>50 \%$ Food energy ${ }^{(50)}$ & $48 \cdot 7$ & 5.9 & $48 \cdot 6$ & $7 \cdot 6$ & $51 \cdot 0$ & $6 \cdot 1$ & $51 \cdot 6$ & 8.0 & 0.007 \\
\hline NMES (\% energy) & $<11 \%$ Food energy ${ }^{(50)}$ & 13.7 & 8.6 & $11 \cdot 6$ & $10 \cdot 2$ & $9 \cdot 4$ & $6 \cdot 0$ & $8 \cdot 8$ & $6 \cdot 4$ & $<0.001$ \\
\hline Total fat (\% energy) & $<35 \%$ Food energy ${ }^{(50)}$ & 37.2 & $5 \cdot 4$ & 37.7 & $7 \cdot 2$ & 31.8 & 5.4 & 31.8 & 7.0 & $<0.001$ \\
\hline $\begin{array}{l}\text { Saturated fat } \\
\text { (\% energy) }\end{array}$ & $<11 \%$ Food energy ${ }^{(50)}$ & $14 \cdot 6$ & $3 \cdot 3$ & 14.9 & 4.8 & 12.0 & $2 \cdot 8$ & $12 \cdot 0$ & 3.7 & $<0.001$ \\
\hline $\begin{array}{l}\text { Monounsaturated fat } \\
\text { (\% energy) }\end{array}$ & & $12 \cdot 2$ & $2 \cdot 4$ & $12 \cdot 4$ & 3.3 & $10 \cdot 2$ & $2 \cdot 2$ & $10 \cdot 1$ & 3.4 & $<0.001$ \\
\hline $\begin{array}{l}\text { Polyunsaturated fat } \\
\text { (\% energy) }\end{array}$ & & 6.0 & 2.0 & 5.9 & $2 \cdot 7$ & 5.9 & 1.9 & $5 \cdot 7$ & $2 \cdot 7$ & 0.892 \\
\hline Protein (\% energy) & & $14 \cdot 1$ & 3.0 & $13 \cdot 8$ & 3.6 & $17 \cdot 1$ & $2 \cdot 8$ & $16 \cdot 7$ & $2 \cdot 8$ & $<0.001$ \\
\hline
\end{tabular}

NMES, non-milk extrinsic sugars.

*Energy, carbohydrate, total fat, saturated fat, monounsaturated fat, polyunsaturated fat and protein intakes are normally distributed and socio-economic differences in mean intakes (italicised values) between the disadvantaged and non-disadvantaged groups are assessed by parametric methods (independent samples $t$ tests). Dietary fibre, NSP and NMES intakes are non-normally distributed and socio-economic differences in median intakes (italicised values) between the disadvantaged and advantaged groups are assessed by non-parametric methods (Mann-Whitney $U$ tests).

lower, while mean Na intakes were higher among the disadvantaged women.

The use of dietary supplements was more prevalent among the non-disadvantaged women than among the disadvantaged women ( $48.4 v \cdot 30 \cdot 5 \%, P=0.011)$, with multivitamins and multiminerals, cod-liver oil, vitamin $\mathrm{C}$, fish oils and $\mathrm{Fe}$ the most commonly used preparations. Even with the contribution from these supplements excluded, however, several micronutrient differences persisted between the two groups. For example, mean niacin intakes $(20.3$ v. $23.9 \mathrm{mg} / \mathrm{d}, P=0.001)$ and median vitamin $\mathrm{C}(59 v .112 \mathrm{mg} / \mathrm{d}, P<0.001)$ and carotene (2528v. $4482 \mu \mathrm{g} / \mathrm{d}, P<0.001$ ) intakes remained significantly lower among the disadvantaged women, while there was also a tendency towards lower folate intakes $(252 v .273 \mu \mathrm{g} / \mathrm{d}$, $P=0.060)$ in this group. Notwithstanding the fact that both group means fell below the $400 \mu \mathrm{g} / \mathrm{d}$ EAR, vitamin A intakes excluding the contribution from supplements were significantly higher in the disadvantaged group. For mineral intakes, mean $\mathrm{Fe}(10.2 v .11 .4 \mathrm{mg} / \mathrm{d}, P=0.011)$ and median $\mathrm{Mg}(250 v .259 \mathrm{mg} / \mathrm{d}, P=0.035)$ intakes were significantly lower among the disadvantaged women than among their non-disadvantaged peers, while mean $\mathrm{Na}$ intakes (3178 v. $2716 \mathrm{mg} / \mathrm{d}, P<0.001)$ remained significantly higher among the poorer women.

\section{Nutrient density}

Micronutrients. Further analyses examined the vitamin and mineral densities of the diet per MJ of energy consumed to elucidate differences in the micronutrient quality of the diet between the disadvantaged and non-disadvantaged cohorts. Here, with the contribution of supplements excluded, nutrient densities for vitamin $\mathrm{B}_{1}$, vitamin $\mathrm{B}_{2}$, niacin, vitamin $\mathrm{B}_{5}$, vitamin
$\mathrm{B}_{12}$, folate, vitamin $\mathrm{C}$, carotene, vitamin $\mathrm{D}$ and vitamin $\mathrm{E}$ were all significantly lower among the disadvantaged women (Table 6). For the minerals investigated, dietary $\mathrm{K}, \mathrm{Fe}, \mathrm{Ca}$, $\mathrm{Mg}$ and $\mathrm{Zn}$ densities per MJ of energy consumed were all significantly lower among the disadvantaged women than among the non-disadvantaged women (Table 6).

\section{Discussion}

\section{Methodology}

The present study aimed to establish how the food group and nutrient intake patterns of young, low-SES Irish women differed from those of their more affluent peers. The sampling frame for the recruitment of our disadvantaged women was developed de novo using small-area population statistics data from the most recent national census, reflecting similar approaches used previously for socio-economic health research in Ireland ${ }^{(56)}$. The post boc profile of our disadvantaged women confirms their low SES and supports the use of such multi-component sampling tools. Notwithstanding this fact, however, the data presented do raise the prospect that the dietary and nutritional deficits identified here may be still more pronounced in areas (and among groups) where these markers of material disadvantage are even more preponderant.

While the exclusive recruitment of our study population from the Greater Dublin area is a limitation, there is no reason to believe that the profound nutritional deficits identified among these young women are not characteristic of other young, urban women of similar SES across Ireland. Although non-probability, purposive sampling was selected for our study design, efforts were made to ensure that the 
Table 5. Differences in vitamin and mineral intakes (including supplements) between the disadvantaged and non-disadvantaged respondents (Mean values and standard deviations; medians and interquartile ranges (IQR), $n$ 216)

\begin{tabular}{|c|c|c|c|c|c|c|c|c|c|c|}
\hline \multirow[b]{3}{*}{ Vitamins } & \multirow[b]{3}{*}{$\mathrm{EAR}^{(52)}$} & \multicolumn{8}{|c|}{ Daily intake including supplements* } & \multirow[b]{3}{*}{$P$} \\
\hline & & \multicolumn{4}{|c|}{ Disadvantaged ( $n$ 153) } & \multicolumn{4}{|c|}{ Non-disadvantaged $(n 63)$} & \\
\hline & & Mean & SD & Median & $\overline{I Q R}$ & Mean & SD & Median & IQR & \\
\hline Vitamin $B_{1}(\mathrm{mg} / \mathrm{d}) \dagger$ & $0.6 \mathrm{mg} / \mathrm{d}$ & 1.6 & 0.7 & 1.5 & 0.8 & 1.8 & 0.8 & 1.6 & 1.5 & 0.170 \\
\hline Vitamin $B_{2}(\mathrm{mg} / \mathrm{d})$ & $1.1 \mathrm{mg} / \mathrm{d}$ & 1.9 & 0.8 & 1.7 & 1.0 & $2 \cdot 1$ & 0.8 & 1.9 & 1.4 & 0.021 \\
\hline Niacin $(\mathrm{mg} / \mathrm{d}) \ddagger$ & Approximately $11 \mathrm{mg} / \mathrm{d}$ & $23 \cdot 0$ & 9.5 & $20 \cdot 8$ & $12 \cdot 1$ & 29.0 & $10 \cdot 2$ & $26 \cdot 7$ & 17.4 & $<0.001$ \\
\hline Vitamin $B_{5}(\mathrm{mg} / \mathrm{d})$ & None defined & 5.8 & $2 \cdot 6$ & $5 \cdot 1$ & $2 \cdot 6$ & $6 \cdot 8$ & $2 \cdot 9$ & $5 \cdot 5$ & 5.5 & 0.028 \\
\hline Vitamin $B_{6}(\mathrm{mg} / \mathrm{d}) \S$ & $1.1 \mathrm{mg} / \mathrm{d}$ & 2.5 & $1 \cdot 2$ & $2 \cdot 2$ & $1 \cdot 3$ & $3 \cdot 2$ & $2 \cdot 2$ & $2 \cdot 8$ & $2 \cdot 2$ & 0.007 \\
\hline Vitamin $B_{12}(\mu \mathrm{g} / \mathrm{d})$ & $1.0 \mu \mathrm{g} / \mathrm{d}$ & 4.7 & $2 \cdot 0$ & $4 \cdot 3$ & 2.5 & $4 \cdot 8$ & 1.7 & 4.6 & $2 \cdot 1$ & 0.383 \\
\hline Folate $(\mu \mathrm{g} / \mathrm{d})$ & $230 \mu \mathrm{g} / \mathrm{d}$ & 286 & 115 & 258 & 141 & 365 & 162 & 324 & 224 & 0.001 \\
\hline Vitamin C $(\mathrm{mg} / \mathrm{d})$ & $46 \mathrm{mg} / \mathrm{d}$ & 89 & 73 & 71 & 77 & 184 & 210 & 149 & 118 & $<0.001$ \\
\hline Vitamin $A(\mu \mathrm{g} / \mathrm{d})$ & $400 \mu \mathrm{g} / \mathrm{d}$ & 517 & 416 & 379 & 355 & 549 & 501 & 316 & 801 & 0.336 \\
\hline Carotene $(\mu \mathrm{g} / \mathrm{d})$ & None defined & 3035 & 2288 & 2528 & 2665 & 5139 & 2943 & 4482 & 3806 & $<0.001$ \\
\hline Vitamin $D(\mu \mathrm{g} / \mathrm{d}) \|$ & $0-10 \mu \mathrm{g} / \mathrm{d}$ & $3 \cdot 1$ & 3.2 & $1 \cdot 8$ & $2 \cdot 1$ & 4.5 & 4.9 & $2 \cdot 8$ & $4 \cdot 8$ & 0.030 \\
\hline Vitamin $E(\mathrm{mg} / \mathrm{d})$ ? & $8 \mathrm{mg} / \mathrm{d}$ & $8 \cdot 7$ & 4.9 & 7.4 & 6.1 & 11.9 & 7.5 & 8.4 & 11.5 & 0.008 \\
\hline $\mathrm{Na}(\mathrm{mg} / \mathrm{d})^{\star *}$ & $2400 \mathrm{mg} / \mathrm{d}$ & 3178 & 923 & 3056 & 1275 & 2716 & 615 & 2641 & 983 & $<0.001$ \\
\hline $\mathrm{K}(\mathrm{mg} / \mathrm{d})$ & None defined & 2969 & 823 & 2858 & 1035 & 3010 & 714 & 2885 & 1081 & 0.687 \\
\hline $\mathrm{Fe}(\mathrm{mg} / \mathrm{d})$ & $10.8 \mathrm{mg} / \mathrm{d}$ & 18.5 & $24 \cdot 0$ & $10 \cdot 9$ & $6 \cdot 1$ & $15 \cdot 2$ & 7.5 & 11.9 & $12 \cdot 7$ & 0.073 \\
\hline $\mathrm{Ca}(\mathrm{mg} / \mathrm{d})$ & $615 \mathrm{mg} / \mathrm{d}$ & 840 & 320 & 799 & 369 & 874 & 250 & 830 & 326 & 0.219 \\
\hline $\mathrm{Mg}(\mathrm{mg} / \mathrm{d})$ & None defined & 252 & 69 & 250 & 85 & 270 & 80 & 261 & 89 & 0.013 \\
\hline $\mathrm{Zn}(\mathrm{mg} / \mathrm{d})$ & $5.5 \mathrm{mg} / \mathrm{d}$ & 8.9 & 2.5 & 8.8 & $3 \cdot 2$ & $8 \cdot 8$ & 1.7 & 8.7 & $2 \cdot 0$ & 0.915 \\
\hline $\mathrm{Cu}(\mathrm{mg} / \mathrm{d})$ & $0.8 \mathrm{mg} / \mathrm{d}$ & 1.4 & 0.5 & $1 \cdot 3$ & 0.8 & 1.3 & 0.5 & 1.2 & 0.8 & 0.134 \\
\hline$P(\mathrm{mg} / \mathrm{d})$ & $400 \mathrm{mg} / \mathrm{d}$ & 1351 & 367 & 1328 & 441 & 1376 & 247 & 1347 & 317 & 0.621 \\
\hline
\end{tabular}

EAR, estimated average requirement.

* Where mean intakes for the disadvantaged and non-disadvantaged groups are in italics $(\mathrm{Na}, \mathrm{Zn}$ and $\mathrm{P}$ ), intakes of that nutrient are normally distributed and comparison between the two groups is by parametric independent samples $t$ tests. Where median intakes for the disadvantaged and non-disadvantaged groups are in italics (vitamins $A$, $\mathrm{B}_{1}, \mathrm{~B}_{2}, \mathrm{~B}_{5}, \mathrm{~B}_{6}, \mathrm{~B}_{12}, \mathrm{C}, \mathrm{D}$ and $\mathrm{E}$, niacin, folate, carotene, $\mathrm{K}, \mathrm{Fe}, \mathrm{Ca}, \mathrm{Mg}$ and $\mathrm{Cu}$ ), intakes of that nutrient are non-normally distributed and comparison is by means of non-parametric Mann-Whitney $U$ tests.

†EAR for vitamin $B_{1}$ set at $72 \mu \mathrm{g} / \mathrm{MJ}$ per $\mathrm{d}$ and assumed at $0.6 \mathrm{mg} / \mathrm{d}$ for a daily energy intake of approximately $8.4 \mathrm{MJ}$.

†EAR for niacin set at $1.3 \mathrm{mg} / \mathrm{MJ}$ per $\mathrm{d}$ and assumed at $11 \mathrm{mg} / \mathrm{d}$ for a daily energy intake of approximately $8.4 \mathrm{MJ}$.

$\S E A R$ for vitamin $B_{6}$ set at $13 \mu \mathrm{g} / \mathrm{g}$ protein per $\mathrm{d}$ and assumed at $1.1 \mathrm{mg} / \mathrm{d}$ for a daily protein intake of approximately $85 \mathrm{~g}$.

$\|$ EAR for vitamin $D$ assumed at $5 \mu \mathrm{g} / \mathrm{d}$ (i.e. half of the maximum of the current RDA).

१ RDA for vitamin E previously set at $8 \mathrm{mg} / \mathrm{d}$ for women aged 18-64 years (Irish RDA, 1983); no current Irish EAR.

${ }^{\star \star}$ Target maximum recommended intake set at $2400 \mathrm{mg} / \mathrm{d}$ by the Food Safety Authority of Ireland ${ }^{(53)}$.

respondents were recruited from a geographically disperse number of areas in North, South, West and City Centre Dublin, with a roughly equal number of low-SES recruitment sites being selected in each region. However, it must be recognised that in the absence of a comprehensive, multi-tiered and explicit sampling frame and the application of a robust probabilistic algorithm to select participants within this frame, our purposive sampling method lacks the rigour of a full probability-based sampling protocol. The propensity for sampling bias is increased where 'judgement' or 'assumption' rather than randomisation distribution is used for participant selection in this way. While use of an area-level sampling frame to identify ED of low SES, along with the equal selection of low-SES ED from the four geographic regions of Greater Dublin, was undertaken in an effort to mitigate such bias and enhance the representativeness of our low-SES sample, the inherent limitations of this sampling protocol must be acknowledged.

The small sample size of our study population also needs to be addressed. By convention, a power of $80 \%$ and a significance level of $5 \%$ were selected to limit the chance of type 1 error (i.e. false positive findings) to less than $5 \%$. The minimum number of disadvantaged and nondisadvantaged respondents required for the comparison of mean macronutrient (fat, saturated fat, carbohydrate and protein) intakes between these two independent samples was calculated using standard errors from a similarly sized population of young women in the NSIFCS ( $n$ 269), according to previously described protocols ${ }^{(57)}$. This yielded a minimum sample size of sixty-three in each group. However, this does not automatically infer that this sample size will suffice for comparative analyses of other nutrient intakes between the low-SES women and their reference group, and this limitation needs to be acknowledged.

Because dietary misreporting constitutes a significant problem in nutritional surveys ${ }^{(58)}$, unreliable dietary records were identified and removed from our food group and nutrient analyses ${ }^{(59)}$. This process, however, only excludes unreliable dietary records on the basis of implausible EI $v$. an individual's calculated energy requirements. It does not eradicate other sources of potential error such as inaccuracy and imprecision of dietary reporting ${ }^{(60)}$ and possible selective, preferential misreporting of certain food groups ${ }^{(61)}$.

It could also be argued that the diet history method facilitates the omission of consumed foods, by failing to provide 'cues' to assist dietary recall in the way that a FFQ might. Additionally, some studies have suggested a lower internal consistency and a greater divergence of population EI with 
Table 6. Differences in vitamin and mineral densities per MJ of energy consumed (excluding supplements) between the disadvantaged and non-disadvantaged respondents

(Mean values and standard deviations; medians and interquartile ranges (IQR), $n$ 216)

\begin{tabular}{|c|c|c|c|c|c|c|c|c|c|c|}
\hline \multirow[b]{3}{*}{ Vitamins } & \multirow[b]{3}{*}{$\mathrm{EAR}^{(52)}$} & \multicolumn{8}{|c|}{ Daily intake per MJ excluding supplements* } & \multirow[b]{3}{*}{$P$} \\
\hline & & \multicolumn{4}{|c|}{ Disadvantaged ( $n$ 153) } & \multicolumn{4}{|c|}{ Non-disadvantaged ( $n$ 63) } & \\
\hline & & Mean & SD & Median & IQR & Mean & SD & Median & IQR & \\
\hline Vitamin $B_{1}(\mu \mathrm{g} / \mathrm{MJ}$ per $\mathrm{d}) \dagger$ & $0.6 \mathrm{mg} / \mathrm{d}$ & 150 & 40 & 140 & 50 & 170 & 40 & 170 & 70 & $<0.001$ \\
\hline Vitamin $B_{2}(\mathrm{mg} / \mathrm{MJ}$ per d) & $1.1 \mathrm{mg} / \mathrm{d}$ & 0.17 & 0.05 & $0 \cdot 16$ & 0.07 & 0.20 & 0.05 & 0.20 & 0.08 & $<0.001$ \\
\hline Niacin (mg/MJ per d)‡ & Approximately $11 \mathrm{mg} / \mathrm{d}$ & $2 \cdot 12$ & 0.78 & $19 \cdot 7$ & 0.87 & 2.93 & 0.85 & $2 \cdot 84$ & 0.96 & $<0.001$ \\
\hline Vitamin $B_{5}(\mathrm{mg} / \mathrm{MJ}$ per d) & None defined & 0.51 & 0.14 & 0.49 & 0.16 & 0.62 & $0 \cdot 12$ & 0.62 & 0.18 & $<0.001$ \\
\hline Vitamin $B_{6}(\mu \mathrm{g} / \mathrm{g}$ protein per $\mathrm{d}) \S$ & $1.1 \mathrm{mg} / \mathrm{d}$ & $27 \cdot 3$ & $6 \cdot 8$ & $26 \cdot 7$ & $6 \cdot 8$ & $26 \cdot 5$ & $5 \cdot 6$ & $26 \cdot 5$ & $9 \cdot 4$ & 0.414 \\
\hline Vitamin $B_{12}(\mu \mathrm{g} / \mathrm{MJ}$ per $\mathrm{d})$ & $1.00 \mu \mathrm{g} / \mathrm{d}$ & 0.47 & 0.19 & 0.43 & 0.20 & 0.55 & 0.18 & 0.52 & 0.20 & 0.001 \\
\hline Folate $(\mu \mathrm{g} / \mathrm{MJ}$ per $\mathrm{d})$ & $230 \mu \mathrm{g} / \mathrm{d}$ & $26 \cdot 3$ & 7.7 & $25 \cdot 6$ & 11.6 & 33.2 & $8 \cdot 1$ & $33 \cdot 1$ & $12 \cdot 4$ & $<0.001$ \\
\hline Vitamin C (mg/MJ per d) & $46 \mathrm{mg} / \mathrm{d}$ & $8 \cdot 2$ & $6 \cdot 2$ & $6 \cdot 3$ & $5 \cdot 8$ & $15 \cdot 3$ & 7.5 & $12 \cdot 8$ & $13 \cdot 7$ & $<0.001$ \\
\hline Vitamin A ( $\mu \mathrm{g} / \mathrm{MJ}$ per $\mathrm{d})$ & $400 \mu \mathrm{g} / \mathrm{d}$ & $35 \cdot 4$ & $16 \cdot 7$ & 32.5 & $18 \cdot 3$ & $33 \cdot 0$ & $12 \cdot 4$ & $32 \cdot 1$ & 14.5 & 0.484 \\
\hline Carotene ( $\mu \mathrm{g} / \mathrm{MJ}$ per $\mathrm{d})$ & None defined & 319 & 245 & 248 & 294 & 623 & 364 & 581 & 458 & $<0.001$ \\
\hline Vitamin D $(\mu \mathrm{g} / \mathrm{MJ}$ per $\mathrm{d}) \|$ & $0-10 \mu \mathrm{g} / \mathrm{d}$ & 0.19 & 0.14 & $0 \cdot 16$ & 0.11 & 0.27 & 0.18 & 0.20 & 0.23 & 0.004 \\
\hline Vitamin E (mg/MJ per d) & $8 \mathrm{mg} / \mathrm{d}$ & 0.71 & 0.26 & 0.69 & 0.34 & 0.91 & 0.27 & 0.89 & 0.41 & $<0.001$ \\
\hline $\mathrm{Na}(\mathrm{mg} / \mathrm{MJ} \text { per } \mathrm{d})^{\star \star}$ & $<2400 \mathrm{mg} / \mathrm{d}$ & 326 & 65 & 323 & 73 & 331 & 71 & 328 & 86 & 0.646 \\
\hline $\mathrm{K}(\mathrm{mg} / \mathrm{MJ}$ per $\mathrm{d})$ & None defined & 307 & 65 & 305 & 71 & 363 & 66 & 357 & 93 & $<0.001$ \\
\hline $\mathrm{Fe}(\mathrm{mg} / \mathrm{MJ}$ per d) & $10.8 \mathrm{mg} / \mathrm{d}$ & $1 \cdot 1$ & 0.3 & 1.0 & 0.3 & 1.4 & 0.3 & $1 \cdot 3$ & 0.4 & $<0.001$ \\
\hline $\mathrm{Ca}(\mathrm{mg} / \mathrm{MJ}$ per d) & $615 \mathrm{mg} / \mathrm{d}$ & 85 & 27 & 81 & 30 & 104 & 25 & 100 & 33 & $<0.001$ \\
\hline $\mathrm{Mg}(\mathrm{mg} / \mathrm{MJ}$ per $\mathrm{d})$ & None defined & 26 & 6 & 25 & 7 & 33 & 6 & 32 & 8 & $<0.001$ \\
\hline $\mathrm{Zn}(\mathrm{mg} / \mathrm{MJ}$ per d) & $5.5 \mathrm{mg} / \mathrm{d}$ & 0.9 & 0.2 & 0.9 & 0.3 & $1 \cdot 1$ & 0.2 & $1 \cdot 1$ & 0.2 & $<0.001$ \\
\hline $\mathrm{Cu}(\mathrm{mg} / \mathrm{MJ}$ per d) & $0.8 \mathrm{mg} / \mathrm{d}$ & 0.15 & 0.05 & 0.13 & 0.08 & $0 \cdot 16$ & 0.06 & 0.13 & $0 \cdot 10$ & 0.224 \\
\hline
\end{tabular}

EAR, estimated average requirement.

*Where the mean intakes per MJ for the disadvantaged and non-disadvantaged groups are in italics (vitamins $B_{1}, B_{2}, B_{6}, E$, folate and $\mathrm{Zn}$ ), intakes of that nutrient per MJ are normally distributed and comparison between the two groups is by means of parametric independent samples $t$ tests. Where the median intakes per MJ for the disadvantaged and non-disadvantaged groups are in italics (vitamins $\mathrm{A}, \mathrm{B}_{5}, \mathrm{~B}_{12}, \mathrm{C}$ and $\mathrm{D}$, carotene, $\mathrm{Na}, \mathrm{K}, \mathrm{Fe}, \mathrm{Ca}, \mathrm{Mg}$ and $\mathrm{Cu}$ ), intakes of that nutrient per $\mathrm{MJ}$ are non-normally distributed and comparison between the two groups is by means of non-parametric Mann-Whitney $U$ tests.

†EAR for vitamin $B_{1}$ set at $72 \mu \mathrm{g} / \mathrm{MJ}$ per $\mathrm{d}$ and assumed at $0.6 \mathrm{mg} / \mathrm{d}$ for a daily energy intake of approximately $8.4 \mathrm{MJ}$.

‡EAR for niacin set at $1.3 \mathrm{mg} / \mathrm{MJ}$ per $\mathrm{d}$ and assumed at $11 \mathrm{mg} / \mathrm{d}$ for a daily energy intake of approximately $8.4 \mathrm{MJ}$.

$\S$ EAR for vitamin $B_{6}$ set at $13 \mu \mathrm{g} / \mathrm{g}$ protein per $\mathrm{d}$ and assumed at $1.1 \mathrm{mg} / \mathrm{d}$ for a daily protein intake of approximately $85 \mathrm{~g}$.

$\| E A R$ for vitamin $D$ assumed at $5 \mu \mathrm{g} / \mathrm{d}$ (i.e. half of the maximum of the current RDA).

I RDA for vitamin E previously set at $8 \mathrm{mg} / \mathrm{d}$ for women aged 18-64 years (Irish RDA, 1983); no current Irish EAR.

${ }^{\star \star}$ Target maximum recommended intake set at $2400 \mathrm{mg} / \mathrm{d}$ by the Food Safety Authority of Ireland ${ }^{(53)}$.

the diet history method compared with weighed intake records ${ }^{(39)}$, while interviewer bias and social desirability bias may be further concerns with this methodology. Nonetheless, as a single-pass, non-presumptive and readily comprehensible way of estimating habitual dietary intakes in an inaccessible population whose intakes are thought to deviate from those of the wider population, this diet history protocol was deemed a more suitable instrument than either a $24 \mathrm{~h}$ recall or a FFQ.

Finally, the inherent limitations of nutrient conversion from dietary records must be stated, as the UK Food Composition database upon which WISP version 3.0 is based, itself has several deficits. For example, the dietary fibre content of most foods as measured by the Southgate ${ }^{(49)}$ and Englyst ${ }^{(50)}$ methods is available on the database. However, the Association of Organic and Analytic Chemists method ${ }^{(62)}$, which measures not just NSP, but also resistant starches, lignins and fructans and is arguably an analytically superior estimate of dietary fibre in food, remains unavailable for many foods in the UK food composition database. Similarly, the food composition databases upon which WISP version 3.0 is based are significantly incomplete for $\mathrm{Se}$, iodine and trans-fatty acids, meaning that output results for these nutrients could not be reliably reported.

\section{Dietary intakes}

There is significant epidemiological evidence from Ireland ${ }^{(3,63)}$ and elsewhere ${ }^{(64-66)}$ that those in the lower socio-economic strata experience poorer health outcomes and have significantly greater premature mortality than their more affluent peers. There is also a wealth of data describing the consumption of lower-quality diets among low-SES groups ${ }^{(6,35,67)}$. Several researchers have linked these two phenomena, highlighting the role of poor diet in socio-economic health inequalities ${ }^{(4,68)}$.

The present study clearly demonstrates the existence of less favourable dietary habits among a group of young, socially disadvantaged women from Dublin, in comparison with those of their more affluent peers. Additionally, while $48.4 \%$ of the non-disadvantaged women reported taking dietary supplements, this estimate fell to $30.5 \%$ among the disadvantaged women. This prevalence of usage among the disadvantaged women is comparable to that reported for all women aged 18-64 years in the National Adult Nutrition Survey (NANS $^{(11)}$. However, the discordant estimates between the two groups also highlight the fact that those who have potentially most to gain from using these products are relatively less likely to use them than their better nourished, wealthier counterparts. 
While the socio-economic differences in dietary intakes highlighted by the present study are profound, the reasons for these differences are more elusive. Putative barriers to healthy diet among low-SES groups include poor nutritional knowledge ${ }^{(69)}$, inadequate food preparation skills ${ }^{(70)}$, high cost of healthy food ${ }^{(71,72)}$, poor local food environment ${ }^{(7,73,74)}$, low perceived control and self-efficacy ${ }^{(32,75,76)}$ and poorer health-related and dietary attitudes ${ }^{(75-77)}$.

\section{Nutritional consequences}

Whatever the origin of these dietary inequalities, the present study highlights the adverse impact that poor dietary habits have on the nutritional intake of low-SES Irish women. The lower dietary fibre and carbohydrate intakes and the higher fat, saturated fat, NMES and $\mathrm{Na}$ intakes observed among the low-SES women are wholly consistent with low-cost diets, which are low in fruit, vegetables, wholemeal bread, breakfast cereals and fish and high in processed meats, butter, full-fat (rather than low-fat) milk, sugar-sweetened beverages, fried potatoes and potato-based snacks ${ }^{(4,78-81)}$. Similarly, the lower absolute and energy-adjusted intakes of vitamin $\mathrm{C}$, folate, carotene, vitamin $\mathrm{D}$, vitamin $\mathrm{E}, \mathrm{K}, \mathrm{Fe}, \mathrm{Ca}$ and $\mathrm{Mg}$ observed among the low-SES women, along with the high prevalence of micronutrient intake inadequacy in this group, are reflective of lower fruit, vegetable, breakfast cereal, unprocessed meat, fish and overall milk intakes, foods that constitute the richest dietary sources of these nutrients.

\section{Health implications}

The health consequences of these aberrant food group and nutrient intake patterns are well established. Diets high in red and processed meats, fat and saturated fat have been associated with increased risk of overweight and obesity ${ }^{(82)}$, elevated LDL-cholesterol levels ${ }^{(83)}$, increased risk of colorectal cancer $^{(84)}$ and greater mortality ${ }^{(85)}$. Similarly, diets high in refined, extrinsic sugars have been associated with overweight and obesity ${ }^{(86,87)}$ and the metabolic syndrome ${ }^{(87)}$, with high intakes of sugar-sweetened beverages, and in particular fructose-containing drinks, being strongly linked to multiple metabolic risk factors ${ }^{(88,89)}$. In the present study, sugary drinks contributed $6 \%$ of the total energy among the disadvantaged respondents $v$. $2 \%$ among the non-disadvantaged women. High alcohol intakes have also been associated with increased cardiometabolic risk ${ }^{(90)}$, increased likelihood of colorectal cancer $^{(91)}$, lower bone mineral density and increased fracture risk $^{(92)}$ and higher overall mortality among socially disadvantaged women ${ }^{(93)}$.

The micronutrient deficits observed among the disadvantaged women also have significant health consequences. For example, low folate intake and status have been associated with increased serum homocysteine levels and cardiovascular risk $^{(94)}$, as well as elevated cancer risk ${ }^{(91,95)}$. Low intakes of several antioxidants including vitamin $\mathrm{C}$ and vitamin $\mathrm{E}$ have been inconsistently associated with increased cardio$\operatorname{vascular}^{(96)}$ and cancer risks ${ }^{(84)}$, while high $\mathrm{Na}$, low $\mathrm{Ca}$ and low $\mathrm{K}$ intakes have been implicated in hypertension ${ }^{(97,98)}$ and in poorer skeletal health ${ }^{(99)}$. Several micronutrient deficits observed among the low-SES women including low $\mathrm{Fe}^{(100)}$, $\mathrm{Ca}^{(101)}$ and folate ${ }^{(102,103)}$ intakes may also exert deleterious effects on the health of their offspring.

\section{Interventions}

The depth and breadth of the nutritional deficits elicited by their poor dietary patterns commend these low-SES women as a primary target for diet-related public health interventions. Fortunately, the candidate food groups for such interventions have been largely established. For example, the significant vitamin and mineral intakes achievable from fruit and vegetables $^{(104,105)}$, breakfast cereals ${ }^{(106,107)}$, wholegrain cereals ${ }^{(108)}$, milk and dairy products ${ }^{(104,109)}$ and fish ${ }^{(108,110,111)}$ are well known. However, apart from their own valuable micronutrient contributions, there is also considerable evidence that increasing the intake of these foods would displace the intake of other more energy-dense, nutrient-deplete foods from the diet. For instance, a higher intake of breakfast cereals has been consistently associated with lower overall fat intakes $^{(106,107)}$. Conversely, high sugar-sweetened beverage intake has been associated with reduced milk intake ${ }^{(112)}$ and higher processed meat consumption with lower fish and poultry intakes ${ }^{(30,31)}$. In the case of high-fat, high-sugar foods, there is clear evidence that their displacement effect on micronutrient-dense foods exerts a deleterious impact on overall nutrient intake and adequacy ${ }^{(36)}$. The interplay between these competing low-energy, micronutrient-rich foods and their high-energy, nutrient-dilute alternatives is, therefore, a critically important consideration in optimising food-based dietary guidelines for young women of low SES.

In the present study, a lower percentage of the disadvantaged women consumed fruit and fruit juices, breakfast cereals, fish, wholemeal bread, low-fat milk and low-fat spread, and a higher percentage of these disadvantaged women consumed sugar-sweetened drinks and potato-based snacks. Low-SES women should, therefore, be advised and facilitated to introduce these foods de novo into their diets. Indeed, there is a synergistic 'displacement' benefit to be gained by explicitly recommending that fruit replace potatobased snacks, that low-fat milk or fruit juices replace sugar-sweetened beverages, that wholemeal bread replace white bread, that fish replace processed red meats, that breakfast cereals replace other breakfast foods such as processed meats and that low-fat spread replace butter.

The fact that fruit and fruit juice, vegetable, breakfast cereal, poultry and wholemeal bread intakes remain lower and that red meat, processed red meat, white bread, sugar-sweetened beverage, fried potato and potato-based snack intakes remain higher in this low-SES group when non-consumers are excluded indicates that frequency of consumption is also a crucial component of these dietary inequalities. Therefore, additional guidance should be given to low-SES women who already consume these healthy foods to increase their frequency of consumption, with the displacement of less healthy alternatives again being a key objective. 


\section{Conclusion}

The present study highlights the presence of endemic food group and nutrient intake deficits among young women of low SES in Ireland. Although a coincident biomarker analysis to assess the nutritional status of these women would have been illuminating, their food and nutrient intakes alone suggest that many may experience deficiency of one or more nutrients. While such nutritional inadequacies portend obvious deleterious effects for these women themselves, their public health impact is compounded by the critical importance of nutrients such as Fe, folate, vitamin A, vitamin $\mathrm{D}$ and $\mathrm{Ca}$ to the optimal growth of their offspring in utero $^{(113,114)}$. Our findings constitute an evidence base for diet-related interventions in such groups and have enabled us to suggest several explicit food-based dietary guidelines. However, psychosocial, sociocultural and ecological impediments to the adoption of such guidelines abound among low-SES women and remain critical barriers to be overcome in the success of any such interventions.

\section{Acknowledgements}

The present study was supported by the Food Safety Promotion Board (SafeFood) (grant no. 03CR/06). We gratefully acknowledge Dr Clare Corish for assistance in the preparation of the final manuscript. Finally, we acknowledge with thanks the generosity of the community development workers and young women who gave of their time to participate in our study, and without whom this work would not have been possible. The contributions of the authors are as follows: D. M. A. M., researcher, was responsible for the fieldwork and manuscript preparation; K. M. Y. was the project supervisor and manuscript editor; J. W. and M. O. were the fieldworkers; C. S. was responsible for the disaggregation of food groups and data analysis; J. M. K. was the principal investigator and grant recipient. None of the authors has any conflict of interests.

\section{References}

1. Barrington R (2004) Poverty is Bad for your Health. Dublin: Combat Poverty Agency.

2. Barry J, Sinclair H, Kelly A, et al. (2001) Inequalities in Health in Ireland - Hard Facts. Dublin: Department of Community Health, General Practice Trinity College.

3. Balanda $\mathrm{K}$ \& Wilde $\mathrm{J}$ (2001) Inequalities in Mortality: A Report on All-Ireland Mortality Data 1989-1998. Dublin: Institute of Public Health in Ireland.

4. James WP, Nelson M, Ralph A, et al. (1997) Socioeconomic determinants of health. The contribution of nutrition to inequalities in health. BMJ 314, 1545-1549.

5. Friel S \& Conlon C (2004) Food Poverty and Policy. Dublin: Combat Poverty Agency in association with Crosscare and the Society of St Vincent de Paul.

6. Friel S, Kelleher CC, Nolan G, et al. (2003) Social diversity of Irish adults nutritional intake. Eur J Clin Nutr 57, $865-875$.

7. Layte R, Harrington J, Sexton E, et al. (2011) Irish exceptionalism? Local food environments and dietary quality. J Epidemiol Community Health 65, 881-888.
8. Harrington KE, Robson PJ, Kiely M, et al. (2001) The North/ South Ireland Food Consumption Survey: survey design and methodology. Public Health Nutr 4, 1037-1042.

9. National Nutrition Surveillance Centre (2003) Dietary Habits of the Irish Population: Results from SLAN (Summary Report). Dublin: National Nutrition Surveillance Centre and Health Promotion Unit, Department of Health \& Children.

10. Harrington J, Perry I, Lutomski J, et al. (2008) SLAN 2007: Survey of Lifestyle, Attitudes and Nutrition in Ireland. Dietary Habits of the Irish Population. Dublin: Department of Health and Children and the Stationery Office.

11. Walton J (2011) National Adult Nutrition Survey - Summary Report on Food and Nutrient Intakes, Physical Measurements, Physical Activity Patterns and Food Choice Motives. Dublin: Irish Universities Nutrition Alliance.

12. Nelson M, Erens B, Bates B, et al. (2007) Low Income Diet and Nutrition Survey Volume 1 - Background, Methods and Sample Characteristics. London: TSO.

13. Shohaimi S, Welch A, Bingham S, et al. (2004) Residential area deprivation predicts fruit and vegetable consumption independently of individual educational level and occupational social class: a cross sectional population study in the Norfolk cohort of the European Prospective Investigation into Cancer (EPIC-Norfolk). J Epidemiol Community Health 58, 686-691.

14. Boylan S, Lallukka T, Lahelma E, et al. (2011) Socioeconomic circumstances and food habits in Eastern, Central and Western European populations. Public Health Nutr 14, 678-687.

15. Wandel M (1995) Dietary intake of fruits and vegetables in Norway: influence of life phase and socio-economic factors. Int J Food Sci Nutr 46, 291-301.

16. Kamphuis CB, van Lenthe FJ, Giskes K, et al. (2007) Perceived environmental determinants of physical activity and fruit and vegetable consumption among high and low socioeconomic groups in the Netherlands. Health Place 13, 493-503.

17. Groth MV, Fagt S \& Brondsted L (2001) Social determinants of dietary habits in Denmark. Eur J Clin Nutr 55, 959-966.

18. Giskes K, Turrell G, Patterson C, et al. (2002b) Socioeconomic differences among Australian adults in consumption of fruit and vegetables and intakes of vitamins A, C and folate. J Hum Nutr Diet 15, 375-385.

19. Metcalf P, Scragg R \& Davis P (2006) Dietary intakes by different markers of socioeconomic status: results of a New Zealand workforce survey. N Z Med J 119, U2127.

20. Dubowitz T, Heron M, Bird CE, et al. (2008) Neighborhood socioeconomic status and fruit and vegetable intake among whites, blacks, and Mexican Americans in the United States. Am J Clin Nutr 87, 1883-1891.

21. Lang R, Thane CW, Bolton-Smith C, et al. (2003) Consumption of whole-grain foods by British adults: findings from further analysis of two national dietary surveys. Public Health Nutr 6, 479-484.

22. Touvier M, Méjean C, Kesse-Guyot E, et al. (2010) Variations in compliance with starchy food recommendations and consumption of types of starchy foods according to sociodemographic and socioeconomic characteristics. Br J Nutr 103, 1485-1492.

23. Aranceta J, Perez-Rodrigo C, Ribas L, et al. (2003) Sociodemographic and lifestyle determinants of food patterns in Spanish children and adolescents: the enKid study. Eur J Clin Nutr 57, Suppl. 1, S40-S44.

24. Siega-Riz AM, Popkin BM \& Carson T (2000) Differences in food patterns at breakfast by sociodemographic 
characteristics among a nationally representative sample of adults in the United States. Prev Med 30, 415-424.

25. Mishra G, Ball K, Arbuckle J, et al. (2002) Dietary patterns of Australian adults and their association with socioeconomic status: results from the 1995 National Nutrition Survey. Eur J Clin Nutr 56, 687-693.

26. Gray L \& Leyland AH (2009) A multilevel analysis of diet and socio-economic status in Scotland: investigating the 'Glasgow effect'. Public Health Nutr 12, 1351-1358.

27. Galobardes B, Morabia A \& Bernstein MS (2001) Diet and socioeconomic position: does the use of different indicators matter? Int J Epidemiol 30, 334-340.

28. Vannoni F, Spadea T, Frasca G, et al. (2003) Association between social class and food consumption in the Italian EPIC population. Tumori 89, 669-678.

29. Ministry of Agriculture Fisheries and Food (1996) National Food Survey 1980, 1995. London: Her Majesty's Stationery Office.

30. Guenther PM, Jensen HH, Batres-Marquez SP, et al. (2005) Sociodemographic, knowledge, and attitudinal factors related to meat consumption in the United States. $\mathrm{J} \mathrm{Am}$ Diet Assoc 105, 1266-1274.

31. Cosgrove M, Flynn A \& Kiely M (2005) Consumption of red meat, white meat and processed meat in Irish adults in relation to dietary quality. BrJ Nutr 93, 933-942.

32. Barker M, Lawrence W, Crozier S, et al. (2009) Educational attainment, perceived control and the quality of women's diets. Appetite 52, 631-636.

33. Deshmukh-Taskar PR, O'Neil CE, Nicklas TA, et al. (2009) Dietary patterns associated with metabolic syndrome, sociodemographic and lifestyle factors in young adults: the Bogalusa Heart Study. Public Health Nutr 12, 2493-2503.

34. Vinkeles Melchers NV, Gomez M \& Colagiuri R (2009) Do socio-economic factors influence supermarket content and shoppers' purchases? Health Promot J Austr 20, 241-246.

35. Darmon N \& Drewnowski A (2008) Does social class predict diet quality? Am J Clin Nutr 87, 1107-1117.

36. Bhargava A \& Amialchuk A (2007) Added sugars displaced the use of vital nutrients in the National Food Stamp Program Survey. J Nutr 137, 453-460.

37. Central Statistics Office (2007) EU Survey on Income and Living Conditions (EU-SILC) 2006. Dublin: Central Statistics Office.

38. Government of Ireland (2007) National Action Plan for Social Inclusion 2007-2016. Dublin: The Stationery Office. www.socialinclusion.ie/documents/NAPinclusionReportPDF.pdf (accessed 8 February 2013).

39. Black AE, Welch AA \& Bingham SA (2000) Validation of dietary intakes measured by diet history against $24 \mathrm{~h}$ urinary nitrogen excretion and energy expenditure measured by the doubly-labelled water method in middle-aged women. Br J Nutr 83, 341-354.

40. Nelson M, Atkinson M, Meyer J on behalf of Nutritional Epidemiology Group UK (1997) Food Portion Sizes: A Photographic Atlas. London: Ministry of Agriculture Fisheries and Food (MAFF).

41. Mills A \& Patel S (1994) Food Portion Sizes, 2nd ed. London: Her Majesty's Stationery Office.

42. McCarthy SN, Harrington KE, Kiely M, et al. (2001) Analyses of the anthropometric data from the North/South Ireland Food Consumption Survey. Public Health Nutr $\mathbf{4}$, 1099-1106.

43. Food Standards Agency (2002) McCance \& Widdowson's The Composition of Foods, 6th ed. Cambridge: Royal Society of Chemistry.
44. Booth ML (2000) Assessment of physical activity: an international perspective. Res Quar Exerc Sport 71, s114-s120.

45. Food \& Agriculture Organization/World Health Organisation/United Nations Universities (1985) Energy and Protein Requirements. Report of a Joint Food \& Agriculture Organization/World Health Organization/United Nations Universities Consultation. WHO Technical Report Series no. 724. Geneva: World Health Organization.

46. Goldberg GR, Black AE, Jebb SA, et al. (1991) Critical evaluation of energy intake data using fundamental principles of energy physiology: 1 . Derivation of cut-off limits to identify under-recording. Eur J Clin Nutr 45, 569-581.

47. Black AE, Coward WA, Cole TJ, et al. (1996) Human energy expenditure in affluent societies: an analysis of 574 doublylabelled water measurements. Eur J Clin Nutr 50, 72-92.

48. Black AE (2000) The sensitivity and specificity of the Goldberg cut-off for EI:BMR for identifying diet reports of poor validity. Eur J Clin Nutr 54, 395-404.

49. World Health Organization/Food \& Agriculture Organization (2003) Diet, Nutrition and the Prevention of Chronic Diseases. Report of a Joint WHO/FAO Expert Consultation. Geneva: World Health Organization.

50. Department of Health (UK) (1991) Dietary Reference Values for Food Energy and Nutrients for the United Kingdom. Report on Health and Social Subjects 41. London: Her Majesty's Stationery Office.

51. Strategic Task Force on Alcohol (2004) Strategic Task Force on Alcohol - Second Report. Dublin: Department of Health \& Children.

52. Food Safety Authority of Ireland (1999) Recommended Dietary Allowances for Ireland 1999. Dublin: Food Safety Authority of Ireland.

53. Food Safety Authority of Ireland (2005) Salt and Health: Review of the Scientific Evidence and Recommendations for Public Policy in Ireland. Dublin: Food Safety Authority of Ireland.

54. Central Statistics Office (2008) EU Survey on Income and Living Conditions (EU-SILC) 2007. Dublin: Central Statistics Office.

55. Central Statistics Office (2007) Census 2006 Volume 5 Ethnic or Cultural Background (Including the Irish Traveller Community). Dublin: Central Statistics Office.

56. Kelly A (2006) Development and Updating the National Deprivation Index for Health \& Health Services Research. Dublin: Small Area Health Research Unit (SAHRU), Department of Public Health \& Primary Care in Trinity College Dublin.

57. Daly LE \& Bourke GJ (2000) Sample size determination. In Interpretation and Uses of Medical Statistics, 5th ed., pp. 276-281. Oxford: Blackwell Science.

58. Livingstone MB \& Black AE (2003) Markers of the validity of reported energy intake. J Nutr 133, Suppl. 3, S895-S920.

59. Samaras K, Kelly PJ \& Campbell LV (1999) Dietary underreporting is prevalent in middle-aged British women and is not related to adiposity (percentage body fat). Int $J$ Obes Relat Metab Disord 23, 881-888.

60. Nelson M, Beresford SAA \& Kearney JM (2004) Nutritional epidemiology. In Public Health Nutrition [MJ Gibney, BM Margetts, JM Kearney and L Arab, editors]. Cambridge: The Nutrition Society \& Blackwell Publishing.

61. Scagliusi FB, Polacow VO, Artioli GG, et al. (2003) Selective underreporting of energy intake in women: magnitude, determinants, and effect of training. J Am Diet Assoc 103, 1306-1313.

62. Prosky L, Asp NG, Schweizer TF, et al. (1992) Determination of insoluble and soluble dietary fibre in food and 
food products: collaborative study. J Assoc Offic Anal Chem 75, 360-366.

63. Layte R, Nolan A \& Nolan B (2007) Poor Prescriptions: Poverty and Access to Community Health Services. Dublin: Combat Poverty Agency.

64. Marmot M, Allen J, Goldblatt P, et al. (2010) Fair Society, Healthy Lives - Strategic Review of Health Inequalities in England Post-2010. London: The Marmot Review.

65. Thomas B, Dorling D \& Davey-Smith G (2010) Inequalities in premature mortality in Britain: observational study from 1921 to 2007. BMJ 341, c3639.

66. Singh GK \& Siahpush M (2006) Widening socioeconomic inequalities in US life expectancy, 1980-2000. Int J Epidemiol 35, 969-979.

67. Mullie P, Clarys P, Hulens M, et al. (2010) Dietary patterns and socioeconomic position. Eur J Clin Nutr 64, 231-238.

68. Anderson AS (2007) Nutrition interventions in women in low-income groups in the UK. Proc Nutr Soc 66, 25-32.

69. McLeod ER, Campbell KJ \& Hesketh KD (2011) Nutrition knowledge: a mediator between socioeconomic position and diet quality in Australian first-time mothers. $J$ Am Diet Assoc 111, 696-704.

70. Larson NI, Perry CL, Story M, et al. (2006) Food preparation by young adults is associated with better diet quality. $J \mathrm{Am}$ Diet Assoc 106, 2001-2007.

71. Monsivais P \& Drewnowski A (2009) Lower-energy-density diets are associated with higher monetary costs per kilocalorie and are consumed by women of higher socioeconomic status. J Am Diet Assoc 109, 814-822.

72. Aggarwal A, Monsivais P, Cook AJ, et al. (2011) Does diet cost mediate the relation between socioeconomic position and diet quality? Eur J Clin Nutr 65, 1059-1066.

73. Zenk SN, Lachance LL, Schulz AJ, et al. (2009) Neighborhood retail food environment and fruit and vegetable intake in a multiethnic urban population. Am J Health Promot 23, 255-264.

74. Inglis V, Ball K \& Crawford D (2008) Socioeconomic variations in women's diets: what is the role of perceptions of the local food environment? J Epidemiol Community Health 62, 191-197.

75. Lawrence W, Skinner C, Haslam C, et al. (2009) Why women of lower educational attainment struggle to make healthier food choices: the importance of psychological and social factors. Psychol Health 24, 1003-1020.

76. Lawrence W \& Barker M (2009) A review of factors affecting the food choices of disadvantaged women. Proc Nutr Soc 68, 189-194.

77. Hearty AP, McCarthy SN, Kearney JM, et al. (2007) Relationship between attitudes towards healthy eating and dietary behaviour, lifestyle and demographic factors in a representative sample of Irish adults. Appetite 48, 1-11.

78. Andrieu E, Darmon N \& Drewnowski A (2006) Low-cost diets: more energy, fewer nutrients. Eur J Clin Nutr $\mathbf{6 0}$, 434-436.

79. Aggarwal A, Monsivais P \& Drewnowski A (2012) Nutrient intakes linked to better health outcomes are associated with higher diet costs in the US. PLoS One 7, e37533.

80. Biltoft-Jensen A, Fagt S, Groth MV, et al. (2008) The intake of saturated fat and dietary fibre: a possible indicator of diet quality. Br J Nutr 100, 624-632.

81. van Lee L, Geelen A, van Huysduynen EJ, et al. (2012) The Dutch Healthy Diet index (DHD-index): an instrument to measure adherence to the Dutch Guidelines for a Healthy Diet. Nutr J 11, 49.
82. Bray GA, Paeratakul S \& Popkin BM (2004) Dietary fat and obesity: a review of animal, clinical and epidemiological studies. Physiol Behav 83, 549-555.

83. Jakobsen MU, O'Reilly EJ, Heitmann BL, et al. (2009) Major types of dietary fat and risk of coronary heart disease: a pooled analysis of 11 cohort studies. Am J Clin Nutr 89, 1425-1432.

84. World Cancer Research Fund/American Institute for Cancer Research (2007) Food, Nutrition, Physical Activity and the Prevention of Cancer: A Global Perspective. Washington, DC: American Institute for Cancer Research.

85. Pan A, Sun Q, Bernstein AM, et al. (2012) Red meat consumption and mortality: results from 2 prospective cohort studies. Arch Intern Med 172, 555-563.

86. Fitch C \& Keim KS (2012) Academy of Nutrition and Dietetics Position of the Academy of Nutrition and Dietetics: use of nutritive and nonnutritive sweeteners. J Acad Nutr Diet 112, 739-758.

87. Livesey G, Taylor R, Hulshof $\mathrm{T}$, et al. (2008) Glycemic response and health - a systematic review and meta-analysis: relations between dietary glycemic properties and health outcomes. Am J Clin Nutr 87, Suppl. 1, S258-S268.

88. Stanhope KL, Schwarz JM, Keim NL, et al. (2009) Consuming fructose-sweetened, not glucose-sweetened, beverages increases visceral adiposity and lipids and decreases insulin sensitivity in overweight/obese humans. J Clin Invest 119, 1322-1334.

89. Hu FB \& Malik VS (2010) Sugar-sweetened beverages and risk of obesity and type 2 diabetes: epidemiologic evidence. Physiol Behav 100, 47-54.

90. Foerster M, Marques-Vidal P, Gmel G, et al. (2009) Alcohol drinking and cardiovascular risk in a population with high mean alcohol consumption. Am J Cardiol 103, 361-368.

91. Giovannucci E (2004) Alcohol, one-carbon metabolism, and colorectal cancer: recent insights from molecular studies. J Nutr 134, Suppl. 9, S2475-S2481.

92. Berg KM, Kunins HV, Jackson JL, et al. (2008) Association between alcohol consumption and both osteoporotic fracture and bone density. Am J Med 121, 406-418.

93. Herttua K, Makela P \& Martikainen P (2007) Differential trends in alcohol-related mortality: a register-based follow-up study in Finland in 1987-2003. Alcohol Alcohol 42, 456-464.

94. Wald DS, Wald NJ, Morris JK, et al. (2006) Folic acid, homocysteine, and cardiovascular disease: judging causality in the face of inconclusive trial evidence. $B M J \mathbf{3 3 3}$, 1114-1117.

95. Figueiredo JC, Levine AJ, Grau MV, et al. (2008) Colorectal adenomas in a randomized folate trial: the role of baseline dietary and circulating folate levels. Cancer Epidemiol Biomarkers Prev 17, 2625-2631.

96. Hamilton KL (2007) Antioxidants and cardioprotection. Med Sci Sports Exerc 39, 1544-1553.

97. McCarron DA \& Reusser ME (2001) Are low intakes of calcium and potassium important causes of cardiovascular disease? Am J Hypertens 14, Suppl. 1, S206-S212.

98. He FJ \& MacGregor GA (2009) A comprehensive review on salt and health and current experience of worldwide salt reduction programmes. J Hum Hypertens 23, 363-384.

99. Teucher B, Dainty JR, Spinks CA, et al. (2008) Sodium and bone health: impact of moderately high and low salt intakes on calcium metabolism in postmenopausal women. J Bone Miner Res 23, 1477-1485.

100. Lee HS, Kim MS, Kim MH, et al. (2006) Iron status and its association with pregnancy outcome in Korean pregnant women. Eur J Clin Nutr 60, 1130-1135. 
101. Bergel E \& Barros AJ (2007) Effect of maternal calcium intake during pregnancy on children's blood pressure: a systematic review of the literature. BMC Pediatr 7, 15-23.

102. Medical Research Council Vitamin Study Research Group (1991) Prevention of neural tube defects: results of the Medical Research Council Vitamin Study. Lancet 338, 131-137.

103. Sinclair KD, Allegrucci C, Singh R, et al. (2007) DNA methylation, insulin resistance, and blood pressure in offspring determined by maternal periconceptional $\mathrm{B}$ vitamin and methionine status. Proc Natl Acad Sci U S A 104, 19351-19356.

104. Vincent E (2008) Fruit, vegetable, and dairy intake predicts nutritional adequacy. J Am Diet Assoc 108, 659-660.

105. Darmon N, Darmon M, Maillot M, et al. (2005) A nutrient density standard for vegetables and fruits: nutrients per calorie and nutrients per unit cost. J Am Diet Assoc 105, 1881-1887.

106. Galvin MA, Kiely M \& Flynn A (2003) Impact of ready-to-eat breakfast cereal (RTEBC) consumption on adequacy of micronutrient intakes and compliance with dietary recommendations in Irish adults. Public Health Nutr 6, $351-363$.

107. Deshmukh-Taskar PR, Radcliffe JD, Liu Y, et al. (2010) Do breakfast skipping and breakfast type affect energy intake, nutrient intake, nutrient adequacy, and diet quality in young adults? NHANES 1999-2002. J Am Coll Nutr 29, 407-418.
108. Maillot M, Darmon N, Darmon M, et al. (2007) Nutrientdense food groups have high energy costs: an econometric approach to nutrient profiling. J Nutr 137, 1815-1820.

109. Nicklas TA, O'Neil CE \& Fulgoni VL III (2009) The role of dairy in meeting the recommendations for shortfall nutrients in the American diet. J Am Coll Nutr 28, Suppl. 1, S73-S81.

110. Gebauer SK, Psota TL, Harris WS, et al. (2006) n-3 Fatty acid dietary recommendations and food sources to achieve essentiality and cardiovascular benefits. Am J Clin Nutr 83, Suppl. 6, S1526-S1535.

111. Bonham MP, Duffy EM, Robson PJ, et al. (2009) Contribution of fish to intakes of micronutrients important for fetal development: a dietary survey of pregnant women in the Republic of Seychelles. Public Health Nutr 12, $1312-1320$.

112. Cavadini C, Siega-Riz AM \& Popkin BM (2000) US adolescent food intake trends from 1965 to 1996. Arch Dis Child 83, 18-24.

113. Rao KR, Padmavathi IJ \& Raghunath M (2012) Maternal micronutrient restriction programs the body adiposity, adipocyte function and lipid metabolism in offspring: a review. Rev Endocr Metab Disord 13, 103-108.

114. Barker DJ, Lampl M, Roseboom T, et al. (2012) Resource allocation in utero and health in later life. Placenta 33, Suppl. 2, e30-e34. 